\title{
Investigating the impact of positive resource interdependence and individual accountability on students' academic performance in cooperative learning
}

\section{Frederick Kwaku Sarfo ${ }^{1}$, Jan Elen ${ }^{2}$}

\author{
${ }^{1}$ University of Education, Winneba, Kumasi Campus \\ ${ }^{2}$ Katholieke Universiteit Leuven
}

\section{Ghana / Belgium}

Frederick Kwaku Sarfo. Department of Educational Leadership. University of Education, Winneba, Kumasi Campus, P.O.Box 1277, Kumasi Ashanti, Ghana . E-mail: sarfofredk2001@yahoo.com

(C) Education \& Psychology I+D+i and Editorial EOS (Spain) 


\section{Abstract}

Introduction. This study addresses two major issues with respect to cooperative learning. The study aims at experimentally investigating the function of positive resource interdependence and individual accountability on academic performance of individuals in cooperative learning.

Method. To achieve the purpose a two by two randomized post-test experimental study was conducted. Descriptive statistics and two way ANOVA were used to analyze the data. .

Results. Interestingly, the results of the study reveal that working on the full content of the information before group discussion results in better academic performance than when each member in the group works on part (positive resource interdependence) of the content before group discussion. Furthermore, it is shown that when members in cooperative learning group are informed that after group work a student will be called randomly from a group for examination and the student's score will be the score for the rest of the group members and the score will be part of the final grade, it strengthens individual and group accountability and consequently facilitates learning. The results show no interaction effect of positive resource interdependence and individual accountability on the academic performance of students under cooperative learning.

Conclusion. The theoretical and practical implications of the results are discussed.

Keywords: Cooperative learning; Positive resource interdependence; Individual accountability; Cognitive load theory; Split-attention effect.

Received: 01/11/11 Initial acceptance: 01/20/11 Final acceptance: 03/17/11 


\section{Investigación del impacto de la interdependencia de recursos positivos y rendición de cuentas en los alumnos}

\section{Resumen}

Introducción. Este estudio aborda dos cuestiones principales en relación con el aprendizaje cooperativo. El estudio tiene como objetivo investigar experimentalmente la función de la interdependencia positiva de recursos y de la ejecución individual con el rendimiento académico de los individuos, durante el aprendizaje cooperativo.

Método. Para alcanzar el objetivo se utilizó un diseño experimental de dos por dos. Se efectuaron análisis estadísticos descriptivos y ANOVA 2 × 2 para analizar los datos.

Resultados. Curiosamente, los resultados del estudio revelan que el trabajo sobre el contenido completo de la información con discusión en grupo produce un mejor rendimiento académico que cuando cada miembro del grupo trabaja en una parte (existe interdependencia positiva de los recursos) del contenido antes de la discusión en grupo. Por otra parte, se demuestra que, cuando a los miembros del grupo de aprendizaje cooperativo se les informa que después del trabajo en grupo de estudiantes se llamará al azar de un grupo para su examen, y la calificación de cada estudiante afectará a la puntuación del resto de los miembros del grupo y la puntuación será parte de la nota final, supone un refuerzo de la responsabilidad individual y de grupo y, por lo tanto, facilita el aprendizaje. Los resultados no muestran ningún efecto de la interacción de los recursos de la interdependencia positiva y la responsabilidad individual sobre el rendimiento académico de los estudiantes en el aprendizaje cooperativo.

Conclusión. Las implicaciones teóricas y prácticas de los resultados se discuten.

Palabras-clave: El aprendizaje cooperativo, la interdependencia positiva de recursos, la responsabilidad individual, la teoría de carga cognitiva, el efecto de Split-atención: Palabras clave. 


\section{Introduction}

Ability to work successfully in a group, critical thinking, problem solving and reflective thinking are elements of modern aims of education and the world of work. Cooperative learning is acknowledged (e.g., Johnson, Johnson, \& Holubec, 1998; Johnson \& Johnson, 1999; Slaving, 1991) as one of the teaching techniques that may facilitate the learning processes for development of knowledge and skills that are aimed at in modern education and required in the world of work.

Cooperative learning is based on the principle of social cognition as proposed by Vygotsky (1978) that social interaction has a dramatic impact on cognitive development. Biological and social development are not isolated from each other, and learning is largely mediated by social interaction between students and more knowledgeable others (teachers, parents, coaches, peers, experts, etc). More recently, cooperative learning has received a lot of attention in the literature on social constructivist and cognitive learning principles, and it is particularly prevalent in education and training institutions and e-learning environments. In spite of the fact that cooperative learning has received remarkable attention in instructional community, empirical studies conducted on its effectiveness reveal mixed findings. On the one hand, research findings (e.g., Adeyemi, 2008; Chang \& Mao, 1999; Fuchs, Fuchs, Mathes, \& Simmons, 1997; Macloughlin, 2009: Onwuegbuzie, Collins \& Jiao, 2009; Slavin, 1991; Vasileiadou, 2009) show that cooperative learning enhances academic performance and acquisition of social or/and psychosocial skills. On the other hand, studies conducted on effectiveness of cooperative learning (e.g., Gillies \& Boyle 2010; Karababa, 2009; Krause, Stark \& Mandl 2009) indicate that cooperative learning does not enhance academic performance. Based on these mixed findings and taking into account the recognition of cooperative learning in instructional practice, there is a need to conduct further empirical studies to investigate or reveal the specific conditions under which cooperative learning is more or less effective; and contribute to the theoretical understanding and practical implications of cooperative learning. In a cooperative learning setting, positive interdependence, more specifically positive resource interdependence and individual accountability are used to strengthen the achievement of the learning goal by the individuals and the entire group (Johnson et al., 1998). This paper experimentally examines the impact of 
positive resource interdependence and individual accountability to strengthen cooperative learning. The paper further examines the interaction effect of positive resource interdependence and individual accountability on students' academic performance under cooperative learning.

\section{Cooperative learning}

Cooperative learning is an instructional technique whereby a group of learners work together on instructional activities to accomplish a shared learning goal. It is an instructional use of small groups so that students work together to maximize their own and each other's learning (Johnson et al., 1998). According to Woolfolk (2001), cooperative learning is an arrangement in which students work in mixed ability groups and are rewarded on the basis of the success of the group. Cooperative learning as defined is not the same as an ordinary group work. In an ordinary group work, students work together without any defined rules. Working together in this manner does not necessarily involve cooperation which is the basic ingredient of cooperative learning.

Cooperative learning helps learners to rehearse, elaborate, and expand their knowledge. As group members question, describe, discuss, and explain; other group members have to reflect, monitor, evaluate, reorganize, and orchestrate their knowledge and skills based on the task at hand. This is expected to result in meaningful learning. Cooperative learning is essential because higher mental functions such as reasoning, critical thinking, and reflection originate in social interactions and are then internalized by the individuals in the group. The purpose of cooperative learning is to make each member a stronger individual in his or her own right (Johnson et al., 1998). Slavin (1991) provides a review of research suggesting that cooperative learning is an effective strategy. A growing body of research (e.g., Chang \& Mao, 1999; Fuchs, Fuchs, Mathes, \& Simmons, 1997; Hendrix, 1999; Macloughlin, 2009) supports the claim that students learn better from each other when they work in a cooperative learning group. In addition, research findings by Onwuegbuzie, Collins, and Jiao (2009) show that cooperative learning group enhances students' academic performance (e,g., retention and transfer of knowledge, problem solving). Furthermore, cooperative learning enables individuals in the group to learn the key skills to survive in society. Therefore, cooperative learning not only enhances academic performance, it also enables individuals to develop social skills (e.g., Gillies \& Boyle, 2010; Karababa, 2009). In the world of work where a "team player" is often considered as a key for business success, cooperative learning 
is considered to be a very useful and relevant instructional technique for teaching and learning..

However, according to Randall (1999) the many benefits of cooperative learning sometimes blind us to abuse its use. Ransdell \& Moberly (2003) report that students perceive cooperative working group to be unscholarly. The major concern raised by students on this is that even if all members do not pull their weight; all students in the group receive the same grade regardless of their contributions. Empirical research (Gillies \& Boyle, 2010) indicates that students socialize during cooperative working group activities rather than work academically. Moreover, research findings by Krause, Stark \& Mandl (2009) and Karababa (2009) show that cooperative learning does not enhance academic performance. The above empirical findings suggest that despite its effectiveness on acquisition of academic and social skills, cooperative learning needs further empirical investigation and should be more refined towards achievement of academic skills. According to Johnson et al. (1998) and Driscoll (2005) to use cooperative learning productively the necessary ingredients should be judiciously considered.

\section{Positive resource interdependence and individual accountability}

Positive interdependence and individual and group accountability are some of the basic ingredients that make cooperative learning successful (Johnson et al.,1998). Positive interdependence is a principle based on social interdependence theory (Johnson et al., 1998). Social interdependence theory indicates that interaction with other people is essential for human survival. In the context of teaching and learning, social interdependence refers to learners' efforts to achieve or develop positive relationships, adjust psychologically and show social competence. Based on this assertion, in cooperative learning positive interdependence is well achieved when individuals in a group perceive that they are linked to each other. This indicates that individuals in the group cannot succeed unless everybody in the group succeeds. Thus the group members understand that they need each other support, explanations, guidance, and success. The failure of one ensures the failure of all. Individuals in the group tend to agree that each individual's efforts benefit not only to herself/himself, but all individuals in the group. Lack of positive interdependence leads to individualistic efforts which is in contrast with the philosophy and purpose of cooperative learning. 
Johnson et al. (1998) identified positive resource interdependence as one of the types of positive interdependence. For this type of positive interdependence, each individual in the group has only a part or a portion of the content or resources needed for the task of the group. In order to achieve the group's goal, individuals' resources (unique contributions) have to be put together. Thus each member has a special and unique role to play to make the entire group successful. The advantage of positive resource interdependence is that each member of the group will have enough time to research and master his or her part (resource) very well and finally the resources may get combined to achieve the group's goal. However, the results of empirical research conducted by Karababa (2009) on the effect of positive resource interdependence within cooperative learning indicate no effect on academic achievement. This finding suggests that there is a need to empirically investigate, expand and improve upon the techniques of positive resource interdependence within cooperative working group to better promote academic achievement. It can be argued that students' limited cognitive resources for processing information could be one of the factors that leads to students' poor performance under positive resource interdependence in cooperative learning. It is established in the literature on instruction and learning that human processing capacity is severely limited (Mayer, 2002; Miller, 1956). Cognitive load theory (Sweller, 1988) supports the proposition that human processing capacity is limited. The main intent of cognitive load theory is that human cognitive architecture (processes) should be a major consideration when designing instruction or teaching to promote learning. There are three types of cognitive load: intrinsic, germane and extraneous cognitive load. According to Sweller, van Merriënboer and Paas (1998), intrinsic cognitive load cannot be directly influenced by the instructional designer/teacher. Germane and extraneous cognitive load refer to cognitive load that arises when learners interact with the instructional materials and can be directly influenced by the instructional designer or teacher. Extraneous cognitive load is cognitive load imposed by cognitive processes not directly relevant to learning (van Merriënboer \& Kirschner, 2007), and it impairs learning. For example, when learners are induced by the design of the learning environment to consult multiple sources of information or when they have themselves to try to identify relevant information in a presentation, this may increase extraneous cognitive load.. Results of the studies conducted by Chandler \& Sweller (1992) and Sweller \& Chandler (1994) indicate that learning computer programming was more difficult when the learner had to use both a manual and a computer than when all the needed material was contained in a manual. Kirschner, Paas,\& Kirschner (2009) propose that the more complex the learning tasks the higher the intrinsic cognitive load, the more efficient and effective it 
will be for individuals to work in group in a manner that reduces the intrinsic cognitive load. However, when learning tasks are so easy that it can be solved by individuals, it may lead to less efficient learning in groups than in individuals alone. This is because the required group communication and coordination activities, also referred to as transaction costs (Kirschner et al., 2009), impose additional extraneous cognitive load that exceed the intrinsic load of the task. In line with positive resource interdependence, it is argued that the constraints of human processing capacity might raise problem on the extent to which individuals in a group mentally process and integrate pieces of information presented by individuals in a group during the cooperative group work or discussion. Consequently, the first research question that this study is experimentally designed to answer is: what is the impact of positive resource interdependence on students' academic performance under cooperative learning?

Moreover, research on cooperative learning reveals that cooperative learning can facilitate learning and motivation if done well, but it can also lead to an opportunity for 'free loading' if individual accountability is not included (Driscoll, 2005; Johnson et al.1998). Individual accountability implies that each member in the group has to develop a sense of responsibility to learn and assist the rest of the group to learn also. Jolliffe (2007) uses the phrase "no hitchhiking" to indicate that each of the group members is accountable for completing his or her part of the work. According to Stahl (1994) the reasons why instructors put students in cooperative learning groups is to help all students in the group to achieve higher academic success individually than were they to study alone. Individual accountability, according to Johnson et al. (1998) is the means to determine as to whether each group member has achieved the group's goal. Keeping the size of cooperative group small, giving an individual test to each student, and given a random oral examinations are some of the suggested techniques to structure and increase individual accountability (Johnson et al., 1998). In random oral examination as a technique to achieve individual accountability, each of the members in a cooperative learning group has equal chances to be selected for the oral examination (test) on the group work/performance. The score any person randomly selected from the group for the test gets would be the score for the rest of the group members and the entire group; and more importantly the score would indicate how well individuals in the group have worked to achieve the learning goal. According to Keller (1987) and Bandura (1997), sometimes learners fail to perform due to fear of the unknown. In order to inculcate confidence in learners and increase their positive self expectation, it is necessary to progressively inform them about the requirements or criteria for evaluation as well as the 
relevance of evaluation of the task they are to perform (Driscoll, 2005; Keller, 1987). Based on this notion the second research questions that this study is experimentally designed to answer is: under what condition (s) would individual accountability have more impact on students' performance under cooperative learning? In addition the study is designed to find out if there an interaction effect of positive resource interdependence and individual accountability on students' performance under cooperative learning.

\section{Purpose of the study}

The purpose of this research is to investigate the students' performance as a function of positive resource interdependence and individual accountability under cooperative learning. The main goal is to add new insight to more effective use of cooperative learning.

Specifically, in this study, from the perspective of positive resource interdependence it is anticipated that during cooperative learning or group discussion, the individual learners first has to attend to the different sources of information presented by the individual members; this is because they do not have adequate prior knowledge of the other information. Then they have to put together the pieces of information that were presented by the different members. And finally they have to reflect, evaluate, and organise the pieces of information to achieve meaningful understanding. Mentally attending to different pieces of information from different sources may induce extraneous cognitive load and result in the use of cognitive resources at the cost of the actual learning process (integrating new information in the existing knowledge base). This could result in learning impairment which would lead to minimal learning in individual learners in the cooperative learning group. For this reason, it is further argued in this study that individual learners in cooperative working group should master the full content or resources required to achieve the group's goal. In this case during group discussion, each learner will have the opportunity to attend, reflect, evaluate, and restructure upon what he/she has learned on the full content. Comparatively this will require little or less cognitive efforts at little or no cost to the learning process; and this may not result learning impairment (as previously described) and therefore would lead to optimum learning in individual learners in cooperative learning group. Therefore to answer the first research question, it is hypothesized that in cooperative learning if all the learners are asked to master the full content before they work cooperatively, it leads to more effective learning than asking each of the learners to master part of the content. 
From the perspective of motivation and self-efficacy beliefs, Bandura (1997) asserts that people have expectations about what actions will produce the desirable outcomes. He called these: outcome expectations. Bandura defined outcome expectations as the judgments people make about the consequences of performance. Positive expectations serve as incentives; and negative expectations serve as disincentives. In describing strategies for stimulating motivation in learners, Keller (1987) suggested that teachers can create positive expectations for success by making it clear just what is expected of students. Given random oral examination has suggested as one of the techniques for increasing individual accountability (Johnson et al., 1998). Based on the assertion of positive (outcome) expectation (Bandura 1997; Keller, 1987), in this article it is argued that individual accountability may yield its maximum effect if the group is informed that at the end of the cooperative group work, a student will be called randomly from the group and examined on the group work. And the score he/she will get will be the score for the rest of individuals in the group and the score will form part of their final grade; thus, motivational strategy has been incorporated in random oral examination. It is believed that in traditional school system the final grade is the criterion to make a final decision on learner's success of a program, and students quite often do not want to get low grades. In addition, if individual learners (or the group members) have pre-knowledge that the outcome of their group work forms part of their final grade, individual learners will be motivated (will have positive outcome expectation) during group discussion and put in much effort in their learning processes. More importantly because any group member can be selected randomly for the test, each member will work harder to achieve the group's goal; also it will become the responsibility of the group to help each member to achieve the group's goal. This is because the group members do not know who will be called randomly for the examination. This finally will maximize the strength of individual and group accountability and consequently leads to more learning gain within cooperative learning. Therefore to answer the second research question, it is hypothesized that when members in cooperative learning are informed that there will be a random examination and the student's score will be the score for the rest of the group members and the score will be part of the final grade, it will strengthen individual accountability and therefore facilitate learning. 


\section{Method}

\section{Participants}

One hundred First Year Bachelor of Science Agriculture Education students were selected from College of Agriculture Education, University of Education, Winneba, Mampong-Campus for the experiment. They were comprised of 81 males and 19 females; their average age was 25 years. They were all following Educational Technology course as a compulsory subject.

\section{Research design}

To test the above stated hypotheses, the study had a 2 by 2 post-test randomised experimental design (see Table 1). Four conditions under positive resource interdependence and individual accountability of cooperative learning were randomly assigned to a Hundred students. The students were selected from one of the university institutions in Ghana. The treatments were combinations of positive resource interdependence (yes (part of the) content) or no (full of the content) and individual accountability (yes (told)) or no (untold).

\section{Table 1. Design of the study}

$$
\text { Individual accountability }
$$

Positive resource

Interdependence

\begin{tabular}{c|c|c|}
\multicolumn{1}{c}{} & \multicolumn{1}{c}{ Yes (told) } & \multicolumn{1}{c|}{ No (untold) } \\
\cline { 2 - 3 } Yes (part content) & $\begin{array}{c}25 \\
\text { (Group A) }\end{array}$ & $\begin{array}{c}25 \\
\text { (Group B) }\end{array}$ \\
\cline { 2 - 3 } No (full content) & $\begin{array}{c}25 \\
\text { (Group C) }\end{array}$ & $\begin{array}{l}25 \\
\text { (Group D) }\end{array}$ \\
\hline
\end{tabular}

\section{Materials}

Materials for the study included 1) content/information on the first six events (out of the nine events of instruction) of instruction (Gagné, 1985) selected from Psychology of learning for instruction (Driscoll, 2005); and 2) Post-test items on the six events of instruction. The six events of instruction are: gaining learners' attention, informing learners 
about the objectives, stimulating recall of students' prior knowledge, presenting stimulus materials, providing guidance and support, and eliciting students' performance. The content on the six events of instruction was divided into 2 sets. The first set (set A) was 50 copies of handouts containing full information or content on all the six events of instruction. For the second set of the content, the six events were randomly divided into 3 . In this regard the second set (set B) of the content consisted of 50 copies of handouts containing detail of part (two events) of information or content on the six events of instruction.

The test items consisted of retention and transfer items (Mayer, 2002) constructed based on the six events of instruction. Actually, the test items were two questions (retention and transfer). The retention test item was "asking individual students to write everything that they know about the first six events of instruction by Gagne". The transfer test item was "asking individual students to write how they would teach a 40 minutes lesson, on how to care for and maintain any two selected farm tools, based on their knowledge of the first six events of instruction". These are the (sample) main test items for the study. In the context of the present study, students' academic performance pertains to retention and transfer.

\section{Procedure}

The experiment was conducted in the classrooms of College of Agriculture Education, Mampong. The experimenter and two assistants used one of the Educational technology periods, consisting of 3 hours, for level 100 students for the experiment. The lecturers (experimenters) briefly introduced the events of instruction for 10 minutes as a topic for the day to all the 100 students in the classroom. After short discussions, the lecturers told the students that they were going to work in cooperative learning groups on the events of instruction. The students were instructed that each group should select a group leader, a group secretary, and members in each group should be tolerant, respect each others views and work cooperatively to achieve the group's goal. The lecturers wrote the goal of the cooperative working groups on the whiteboard and read it aloud to all the students. The goal was that 1) the students should read the materials on the events of instruction very well individually for 40 minutes, 2) then discuss or work together in groups for 50 minutes, and each group should briefly write one page on how the six events would help them to plan and teach a selected topic in agriculture effectively in the classroom. Then, the lecturers randomly divided the students into 4 groups (25 in each group). The four groups were randomly assigned to four 
Investigating the impact of positive resource interdependence and individual accountability on students' academic performance in cooperative learning

treatments or conditions under positive resource interdependence and individual accountability:

- Condition A (Group A) - Positive resource interdependence (Yes) (part content) with individual accountability ( whereby members in their cooperative working groups would be told that at the end of their cooperative work, a student would be randomly selected from the group for a test on the content \{the six events of instruction\}); and the marks that she/he would get would be the marks for each members in a group and the marks will be part of their final grade.

- Condition B (Group B) - Positive resource interdependence (Yes) (part content) without individual accountability (whereby members would not be told that a student will be selected randomly for a test on the content \{the six events of instruction\})

- Condition C (Group C) - Positive resource interdependence (No) (full content) with individual accountability (whereby members in their cooperative working groups would be told that at the end of their cooperative work, a student will be randomly selected from the group for a test on the content (the six events of instruction\}) and the marks that she/he would get would be the marks for each members in the group; and the marks will be part of their final grade, and .

- Condition D (Group D) - Positive resource interdependence (No) (full content) without individual accountability (whereby members will not be told that a student will be selected randomly for a test on the content [the six events of instruction\})

The experimenters made sure that they had addressed each group separately so that no group could hear what was told to the other groups. Each of the 4 groups was further randomly divided into five cooperative learning groups - five students in each cooperative learning group. All the groups were separated, they were asked to start work and they were supervised by the experimenters. Since students were randomly assigned to the four conditions and cooperative groups were randomly formed, it is assumed that the groups were equivalent.

After the students had worked for the required number of minutes, the cooperative work was dissolved, and the students were asked to sit down properly for the class to continue. Then the retention and transfer questions on the six events of instruction printed on a question paper were administered to all the students to answer. They were asked to write 
their group number, index number, and answer all the questions on the question paper. Students were given 25 minutes and instructed to do independent work. They were supervised by the experimenters. The test papers were collected at the end of the 25 minutes, and they were given to one of the Agriculture Education lecturers to mark. After the marking the lecturer discussed the results with the experimenter and the data were finally collated. ANOVA was employed to analyze the data.

\section{Results}

The dependent variables were the students total test scores (academic performance) for the retention and transfer test items. The independent variables were 1) positive resource interdependence (full and part) and 2 (individual accountability (told and untold) (table 2)

Table 2. The overview of the mean scores of students in the various conditions

\begin{tabular}{|c|c|c|c|c|}
\hline & & Positive Resour & interdependence & \\
\hline & & Yes/Part & No/Full & Total \\
\hline Individual & Told/Yes & $\mathrm{N}=24$ & $\mathrm{~N}=24$ & $\mathrm{~N}=48, \mathrm{M}=11.35$ \\
\hline accountability & & $\mathrm{M}=10.35$ & $\mathrm{M}=12.35(\mathrm{SD}:$ & $(\mathrm{SD}: 2.31)$ \\
\hline & & $(\mathrm{SD}: 2.4)$ & $1.65)$ & \\
\hline & Untold/No & $\mathrm{N}=25$ & $\mathrm{~N}=25$ & $\mathrm{~N}=50, \mathrm{M}=9.63$ \\
\hline & & $\mathrm{M}=9.00$ & $\mathrm{M}=10.26(\mathrm{SD}:$ & (S.D: 3.02) \\
\hline & & 2.94) & $3.04)$ & \\
\hline & Total & $\mathrm{N}=49$ & $\mathrm{~N}=49$ & $\mathrm{~N}=98, \mathrm{M}=10.48$ \\
\hline & & $M=9.66$ (S.D: & M =11.29(S.D: & (S.D:2.82) \\
\hline & & $2.78)$ & 2.66 & \\
\hline
\end{tabular}

Table 2 shows the overview of the mean scores of students under positive resource interdependence and individual accountability in various conditions of cooperative learning. Two way ANOVA revealed main effects of the treatments. Thus there was statistically significant difference between academic performance of positive resource interdependence. Cooperative learning groups who received full content and those who received part content $(F(1,97)=9.67, P=.002$ eta square $=.09)$ differed; indicating that students in cooperative 
learning groups who received full content academically performed better than those who received part content. In addition, the two way ANOVA showed a statistically significant effect of individual accountability on performance in cooperative learning groups. Students who were told outperformed those who were not told $(F(1,97)=10.82, P=.001$, eta square $=$ .10). No interaction effects were established (figure 1).

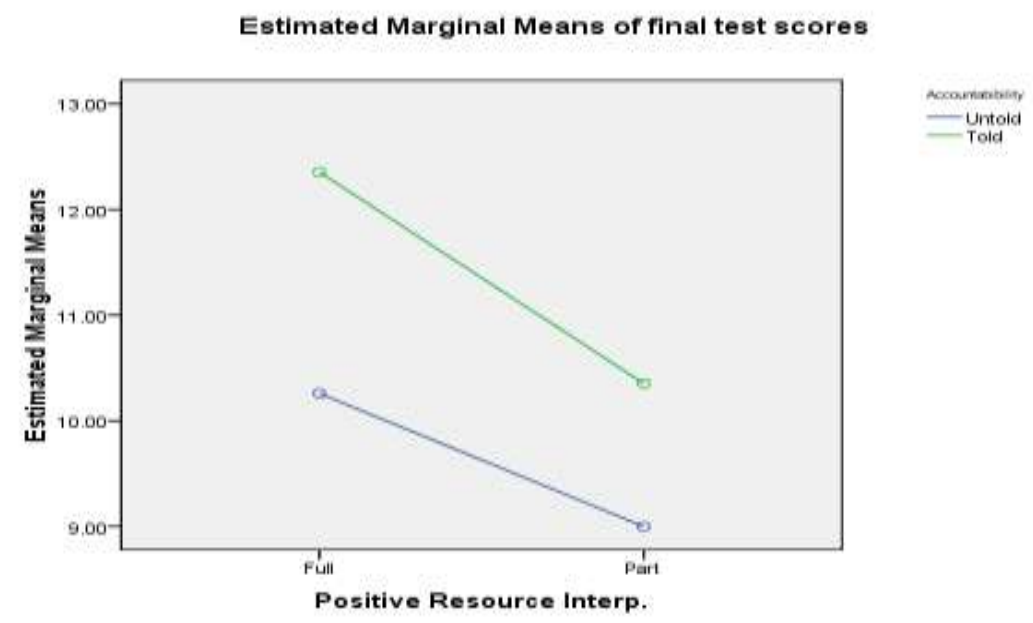

Figure 1.Iinteraction effect of positive resource interdependence and individual Accountability

\section{Discussion and conclusion}

This study empirically investigated the impact of: 1) positive resource interdependence and 2) individual accountability on students' academic performance under cooperative learning. Furthermore, the study investigated the interaction effect of positive resource interdependence and individual accountability on students' academic performances under cooperative learning. To achieve the goal of the study the following research hypotheses were formulated: 1) In cooperative learning, if all the learners are asked to master the full content before they work cooperatively to achieve the group's goal, it leads to more effective learning than asking each of the learners to master part of the content; 2) when members in cooperative learning group are informed that after group work a student will be called randomly from a group for examination and the student's score will be the score for the rest of the group members and the score will be part of the final grade, it strengthens individual and group accountability and therefore facilitates learning; and 3) there is interaction effect of positive resource interdependence and individual accountability on the 
effect of students' academic performance under cooperative learning. Two by two randomized post-test experimental design was conducted to test the formulated hypotheses. The experiment was conducted in real classroom settings and the result is discussed in turn.

First, the results of the study revealed that when each member in the cooperative working group works on the full content of the information before group discussion they academically performed better than when each member in the group works on the part of the content before group discussion. The result indicates that learning is more effective if each member in the cooperative working group is asked to master the full content before the group discussion. In other words, the result of the study indicates that learning is less effective if each member in the cooperative working group is asked to master part of the content before group discussion. The finding that positive resource interdependence (if individuals in the group master part of the content before they work in the group) under cooperative working group is less effective is consistent with the research finding by Karababa (2009). However, the result of this study and Karababa (2009) contradict the assertion by Johnson et al. (1998) that positive resource interdependence is one of the ingredients that enhance cooperative working group. As explained in the first hypothesis, one possible theoretical reason for ineffectiveness of positive resource interdependence is that students may not have adequate cognitive resources to enable them connect pieces of information - presented by individual members in cooperative learning - together in a meaningful way to promote effective learning. More specifically, this phenomenon can be theoretically explained by Split-attention effect under cognitive load theory. Split-attention effect according to Sweller et al (1998) is defined as any impairment in learning that occurs when a learner must mentally integrate two or more sources of information. In line with this it can be argued based on the finding of the present study that split-attention effect has negative impact on positive resource interdependence under cooperative learning. An alternative explanation immediately refers to time-on-task. In the resource dependent conditions, students first study part of the materials for a substantial amount of time, the time they can spend on working on the entire set of materials is limited. Hence during cooperative learning time they have to do multiple things in a limited time-frame: get to know the remainder of the content, integrate these materials and apply the materials in order to execute the collaborative task. In the resource independent condition, students first learn all the materials, during cooperative learning time they only have to do less work as compared to those who had part content. In other words they have more time on task. Another possible explanation is that students under part content might not 
have adequate prior knowledge to enable them achieve meaningful understanding on the six events of instruction as compared to students under full content. This explanation is in line with Moos' and Azevedo's (2008) assertion that students with higher prior domain knowledge tend to use self-regulated strategies (such as monitoring, planning) during learning, resulting in more successful learning. In contrast, students with low prior domain knowledge may not be able to simultaneously process information and apply self-regulated strategies, resulting in less successful learning..

The result that members in the cooperative working group academically perform better when each member learns the full content before group discussion is very significant finding. The finding supports the theoretical understanding of cognitive load theory and Splitattention effect by (Sweller, 1998) in students learning. Moreover, it confirms the relevance of cognitive load theory and split-attention effect in classroom teaching, and therefore advises teachers about the kind of information/content they should provide to students for cooperative working group. The result also advises teachers/instructors to be very careful when dividing topics among individual students/groups to go and research on and come and present in the classroom. Furthermore, the finding reveals the importance of cognitive load theory and prior domain knowledge in cooperative working group as an instructional strategy. Thus, it adds new insights to the existing (cognitive load theory) theory. In addition, and more importantly, the result provides the theoretical explanation on why positive resource interdependence under cooperative learning may not be effective. The results suggest that in a context of content interdependence sufficient time needs to be provided for students to get to know and understand the entire context prior to a cooperative learning task. Since it seems there is no similar finding in the literature at the moment, the results call for additional empirical research to confirm or challenge the finding. One condition might be a condition in which students get sufficient time to explain to each other their part of the content. Another limitation of the present study is that the students' prior knowledge was not measured; the future study might design to measure students' prior knowledge. The future study could also design to investigate students' performance under the various conditions in terms of the transfer test item and retention test item

Second, the result of the study reveals that when members in cooperative learning group are informed that after group work a student will be called randomly from a group for examination and the student's score will be the score for the rest of the group members and 
the score will be part of the final grade, it strengthens individual and group accountability and therefore facilitates learning. Since the performance of those who were not informed was less effective, it is argued that, as indicated in the second hypothesis, when strategy (such as informing learners about how a test will be conducted, how the marks will be awarded, and what the marks will be used for) is incorporated in the oral random examination, it enhances individual accountability and therefore promote learning in cooperative learning group. This finding is in line with Keller (1987) and Driscoll (2005) proposition that if teachers make it clear to learners what is expected of them during teaching and learning activities learning will be successful. As it is explained in the second hypothesis, in cooperative learning if individual learners (or the group members) have pre-knowledge that the outcome of their group work forms part of their final grade, individual learners will have positive outcome expectation during group discussion and put in much effort in their learning processes.

One possible explanation for this positive finding is that since most of the students attach so much importance to their final grade each of them would make sure to work harder for the group success. In addition, since those who are academically good wouldn't like to perform poorer in the final grade, and they don't know the one who will be called from the group for the test, they will take full responsibility to help those who are not academically good in the group to perform well. Moreover, it will become the full responsibility of every member in the group to make sure that he/she is contributing effectively and also to understand so that in case he/she is called for the test he/she could perform.

Again, this finding is new and very significant. First, the finding adds new insight into the effectiveness of individual accountability under cooperative learning. Second, the finding reveals and extends the effectiveness of Keller's motivational strategy to cooperative working group. Third, it supports the theoretical understanding of Keller's motivational strategy. Forth it advises instructional practitioners (instructional designers and teachers) about how to make best use of individual accountability to promote effective learning in cooperative working group in the classroom. Since the finding looks new in the literature the result calls for further empirical studies to validate or challenge the finding.

Finally, it is interesting to note that we have two main effects and no interaction effects. This means that content interdependence and individual accountability are important ingredients of cooperative learning in their own right. 


\section{References}

Adeyemi, B.A. (2008). Effect of cooperative learning and problem solving strategies on Junior Secondary School Students's achievement in social studies. Electronic Journal of Research in Educational Psychology, 6(3), 691-708. Retrieved $18^{\text {th }}$ March,2011 from http//www.investigationpsicopedagogical.org/revista/new/English/ContadorArticulo.php?181

Bandura, A. (1997). Self-efficacy: The exercise of control. New York: W. H. Freeman.

Chandler, P., \& Sweller, J. (1992). The split-attention effect as a factor in the design of instruction. British Journal of Educational Psychology, 62, 233-246.

Chang, C. Y. \& Mao, S. L, (1999). The effect of students' cognitive achievement when using the Cooperative learning methods in earth science classrooms. School Science and Mathematics, 99 (7), 374-379.

Driscoll, M. P. (2005). Psychology of learning for instruction. Boston: Pearson Education Inc.

Fuchs, D., Fuchs, L., Mathes, P. \& Simmons, D., (1997). Peer assisted learning strategies:making classrooms more responsive to diversity. America Educational Research Journa,l 34, 174-206.

Gillies, R. and Boyle, M. (2010). Teachers' reflection on cooperative learning: issues on Implementation. International Journal on Research and Studies, 26 (4), 933-940.

Hendrix, J.C. (1999). Connecting cooperative learning and social studies. The Clearing House, 7 (1), 57-60.

Johnson, D. \& Johnson, R. (1999). Learning together and alone: cooperative, competitive, and individualistic learning. Boston: Allyn and Bacon.

Johnson, D., Johnson R. \& Holubec, E. (1998). Cooperation in the classroom. Boston: Allyn and Bacon.

Jollife, W. (2007). Comparative learning in the classroom: putting it into practice. Retrieved June 20, 2009 from

http://books.google.com.jm/books?id=YCHKT$\mathrm{xa} 4 \mathrm{C} \& \mathrm{pg}=\mathrm{PA} 1 \& \mathrm{dq}=$ cooperative+learning $\& 1 \mathrm{r}$ 
Karababa, Z. C. C. (2009). Effect of cooperative learning on prospective teachers' achievement and social interaction. Hacettepe University Journal of Education, 36, 3249.

Keller, J.M. (1987). Strategies for stimulating the motivation to learn. Performance and Instruction Journal, 1-7

Kirschner, F., Paas F., \& Kirschner, P.A. (2009). A cognitive load approach to collaborative learning: united brains for complex learning. Educational Psychology Review, 21, 31 42.

Krause, U. M., Stark, R. \& Mandl, H. (2009). The effect of cooperative and feedback on eLearning in statistics. Learning and Instruction 19 (2), 158-170.

Maclouglin, C.S. (2009). Positive peer group intervention: an alternative to individualized interventions for promoting prosocial behaviors in potentially disaffected youth. Electronic Journal of Research in Educational Psychology, 7(3), 1131-1156. Retrieved $18^{\text {th }}$ March, 2011 from

http//www.investigation-

psicopedagogical.org/revista/new/English/ContadorArticulo.php?370

Mayer, R. E. (2002). Multimedia Learning. Cambridge, UK: University Press.

Miller, G. A. (1956). The magic number seven, plus or minus two: some limits on our capacity for processing information. Psychological Review, 63, 81-97.

Moos, D.C. \& Azevedo, R. (2008). Self-regualted learning with hypermedia: the role of prior domain knowledge. Contemporary Educational Psychology 33 (2008), 270-298

Onwuegbuzie, A. J., Collins, K. M. T., Jiao, O. G. (2009). Performance of cooperative learning Group in a postgraduate education research methodology course: the role of social Interdependence. Active Learning in Higher Education, 10(3), 265-277.

Randall, V. (1999). Cooperative learning: abused and overused. The Education Digest, 65(2), 29-32.

Ransdell, M. \& Moberly, D. (2003). A journey into cooperative learning with teachereducation students. Retrieved December 3, 2008 from http://www.usca.edu/essays/vol62003/ransdall.pd 
Investigating the impact of positive resource interdependence and individual accountability on students' academic performance in cooperative learning

Slavin, R.E. (1991). Synthesis of research on cooperative learning. Educational Leadership, $48(5), 71-82$.

Stahl, R. (1994). The essential elements of cooperative learning in the classroom. Retrieved: June,20,2009from

ERICJ.http://www.eric.ed.gov./ERICDocs/data/ericdocs2sq/content_storage_10/000001 9b/80/15/a4/6f.pdf.

Sweller, J. (1988). Cognitive load during problem solving: effects on learning. Cognitive Science, 12, 257-285.

Sweller, J., \& Chandler, P. (1994). Why some material is difficult to learn. Cognition and Instruction, 12, 185-233.

Sweller, J., van Merrienboer, J. J., G. \& Paas, F. (1998). Cognitive architecture and instructional design. Educational Psychology Review, 10(3), 251-296.

Van Merrienboer, J. J. G. \& Kirschner, P. A. (2007). Ten steps to complex learning: a systematic approach to four-component instructional design. London: Routledge.

Vasileiadou, M. (2009). Cooperative learning and its effects on pre-primary, marginalized children. Emotional and Behavioral Difficulties, 14(4), 337-347.

Vygotsky, L. S. (1978). Mind in society. Cambridge, MA: Havard University Press.

Woolfolk, A. (2001). Educational psychology. Boston: Allyn and Bacon. 
Frederick Kwaku Sarfo et al.

[This page intentionally left blank] 